\title{
PSICOLOGIA DO TRÂNSITO
}

\author{
Psychology of Traffic
}

\section{Fabiola Cristina Carneiro ${ }^{1}$ Rafaela Roman de Faria ${ }^{2}$}

Neuza Corassa graduou-se em psicologia pela Universidade Tuiuti do Paraná (UTP), atua como psicóloga na área clínica. É idealizadora e fundadora do CPEM - Centro de Psicologia Especializado em Medos em Curitiba. Foi uma das pioneiras no Brasil a desenvolver estudos sobre o medo de dirigir, hoje conhecido como a "Síndrome do Carro na Garagem". É voluntária do projeto de parceria do CRP/08 com a Vara de Delitos de Trânsito de Curitiba, contribuindo na elaboração do material e palestras, "Sensibilização para o trânsito" (Prêmio Volvo de Segurança no Trânsito, em 2003). É autora de dois livros relacionados ao comportamento dos motoristas no trânsito. Para essa edição, Neuza Corassa concedeu uma entrevista, relatando brevemente sua experiência no atendimento a indivíduos com medo e fobia de dirigir.

Pergunta: Como surgiu o interesse em trabalhar nessa área?

Resposta: Há alguns anos, eu atendia crianças em meu consultório de psicologia e observei que muitas mães que traziam seus filhos não dirigiam apesar de já possuírem carteira de habilitação e muitas vezes carros. Comecei a estudar as fobias, pois tive a teoria na faculdade. E passei a organizar uma maneira de trabalhar mais diretamente a dificuldade daquelas mulheres, pois não havia cursos específicos sobre este tema. Foi aí que nasceu o primeiro estudo e foi criado o termo "Síndrome do carro na garagem".

Pergunta: Em qual linha teórica é fundamentado o seu trabalho?

Resposta: Cognitiva Comportamental.

Pergunta: Qual é o perfil da clientela que apresenta medo de dirigir?

Resposta: Na maioria das vezes, trata-se de pessoas extremamente responsáveis, que dão conta dos compromissos assumidos. São confiáveis, organizadas, detalhistas, sensíveis e inteligentes. Preocupamse com os outros, com seus problemas e procuram não ferir quem quer que seja.

\footnotetext{
Acadêmica de Psicologia 10 período PUCPR. e-mail: fabicarneiro@hotmail.com

Acadêmica de Psicologia $10^{\circ}$ período PUCPR. e-mail: rafaela_faria22@hotmail.com
} 
Porém, não gostam de críticas. A crítica alheia pode magoá-las, irritá-las. Não admitem errar. Por isso evitam fazer determinadas coisas. Entre fazer e errar, mesmo que seja um erro natural, evitam fazer.

As pessoas que têm fobia de dirigir são, na maior parte, mulheres, entre 30 e 45 anos de idade. Quase todas têm a vida profissional ativa. Em geral não só dão conta da vida profissional como também administram a casa. As que têm como tarefa única a administração do lar se destacam pela maneira que conduzem a vida familiar, orientam os filhos e atendem às necessidades de todos.

Os homens também sofrem. Os atingidos pela "síndrome do carro na garagem", em geral são muito capazes e sensíveis às coisas belas da vida, como a música, a arte, a natureza. Enfim, procuram viver num mundo menos agressivo. Não aceitam a agressividade do trânsito, por isso rejeitam fazer parte dele.

Pergunta: Como diminuir o sofrimento de quem se encontra nessa situação (medo de dirigir)?

Resposta: Um dos caminhos é o conhecimento do universo do problema. É preciso conhecer o perfil das pessoas que têm medo de dirigir, as possíveis causas desse medo, suas implicações no contexto histórico-social, a história das pessoas e as circunstâncias associadas ao ato de dirigir, para que possa dar-se início ao trabalho.

A solução para o medo de dirigir não depende apenas da força de vontade. Primeiro é preciso verificar como está o volante de nossa vida para em seguida definir as atitudes a tomar no volante do carro.

Pergunta: Como é desenvolvido o trabalho frente às fobias?

Resposta: As pessoas com fobia de dirigir são atendidas em quatro etapas bem definidas:

$\mathrm{Na}$ primeira etapa realizo a Análise Funcional (Volante da Vida), terapeuta e paciente levantam as exigências, preocupações e ansiedades que a pessoa apresenta no volante da vida e que podem estar indo para o volante do carro.

No segundo momento, por meio de um relaxamento muscular profundo, estimula-se a liberação das endorfinas que irão neutralizar a noradrenalina que provoca tremedeiras, levando às dificuldades no carro, como, por exemplo, o controle dos pedais.
Segue com a Hierarquia/foco fóbico. Nessa etapa, são levantados e hierarquizados os principais medos do paciente ao dirigir o automóvel. Os mais comuns estão relacionados ao trânsito intenso e às reações dos demais motoristas, às manobras e às rampas. Identificadas todas essas questões, elas serão trabalhadas primeiramente na sessão com o terapeuta e depois pela pessoa, com seu instrutor, na próxima etapa que envolve a prática com o carro.

Por último, trabalho a reciclagem, utilizo este termo pelo fato de a maioria das pessoas já possuírem carteira de habilitação. O CPEM costuma treinar e indicar profissionais habilitados a trabalhar com este perfil. Esses instrutores são pessoas capazes, atenciosas e sensíveis às dificuldades da pessoa com fobia, dando-lhe o tempo necessário para que possa executar, de maneira gradual, a atividade de dirigir.

A partir da escolha do instrutor pelo paciente, inicia-se um trabalho em conjunto, onde é combinado um plano de trabalho (inicialmente envolvendo a repetição de um ou dois trechos que serão mais utilizados pela pessoa) e este realiza as lições práticas com o instrutor, trabalhando na sessão com o terapeuta suas dificuldades e conquistas.

Posteriormente, passa para o procedimento de "meia independência", onde dirige o seu carro, sendo seguido pelo instrutor.

Em um terceiro momento, repete os trajetos sozinho, o instrutor fica ausente até que novos trajetos sejam incluídos. A alta ocorre quando o objetivo que trouxe a pessoa ao CPEM foi atingido. Em média é de doze a vinte sessões.

Pergunta: A agressividade está bastante presente no trânsito e o tempo no congestionamento faz parte do dia-a-dia da maioria das pessoas. O que você ressalta sobre esses aspectos?

Resposta: $\mathrm{Na}$ pesquisa "O uso do carro como extensão da casa" ficou constatado que o indivíduo sai do seu espaço privado, vai para um espaço público e continua a se comportar como se estivesse em casa. Desta forma, o indivíduo não tem consciência do espaço coletivo e acaba vendo o outro motorista como inimigo ou intruso, conseqüentemente, torna-se agressivo.

Em relação ao tempo no congestionamento, nem as pessoas nem as cidades estavam preparadas para tantos carros. Está acontecendo um 
processo inverso: no volante das vidas as pessoas estão correndo mais. No trânsito estão parando pelo número de carros, mas as pessoas têm uma tendência de usar a mesma velocidade da vida. O congestionamento é fato, mas aproveitar ou desperdiçar o tempo que você passa nele é uma escolha sua.

Pergunta: Comente sobre os jovens que dirigem sem carteira e também sobre os que conduzem alcoolizados.

Resposta: A respeito dos jovens que dirigem sem carteira acredito que é responsabilidade dos pais, eles precisam se envolver. Os jovens irão insistir, porém os pais devem ser firmes. Guiar é muito mais que dirigir e eles se arremessam para o trânsito sem preparo.

Não me conformo com o número de mortes devido aos que dirigem alcoolizados. Dediquei minha monografia aos que perderam alguém no trânsito. Isso desestrutura a família, é muito grave e estamos fazendo pouco por isso.

Pergunta: Que dicas você deixaria para quem quer ingressar nesta área?

Resposta: Acredito que essa é uma área em crescimento, faz-se necessário investir em pesquisas e não esperar muito apoio. 